\title{
Adult Cerebellar Ataxia, Axonal Neuropathy, and Sensory Impairments Caused by Biallelic SCO2 Variants
}

Benoit Rucheton, PharmD,* Claire Ewenczyk, MD, PhD, * Pauline Gaignard, PharmD, PhD, Jean-Madeleine de Sainte Agathe, MD, Anne-Laure Fauret, PharmD, PhD, Virginie Saillour, PhD, Sarah Leonard-Louis, MD, PhD, Valerie Touitou, MD, PhD, and Fanny Mochel, MD, PhD

Neurol Genet 2021;7:e630. doi:10.1212/NXG.0000000000000630

SCO2 encodes a 266-amino-acid metallochaperone involved in copper supply for the assembly of cytochrome c oxidase or complex IV (CIV). CIV is the terminal enzyme of the energytransducing respiratory chain that transfers electrons from reduced cytochrome $\mathrm{c}$ to oxygen via 3 copper ions. ${ }^{1}$ SCO2 pathogenic variants were first identified in children with hypertrophic cardiomyopathy, often associated with developmental delay and lactic acidosis ${ }^{2}$ (Figure, A). $\mathrm{SCO} 2$ variants were then reported in children with Leigh syndrome ${ }^{3}$ and early-onset axonal neuropathy, ${ }^{4}$ possibly associated with cerebellar ataxia ${ }^{5}$ (Figure, A). Here, we report heterozygous missense $\mathrm{SCO} 2$ variants in a 48 -year-old patient presenting with a complex neurologic and sensory phenotype comprising cerebellar ataxia, sensory neuronopathy, deafness, pigmentary retinopathy, and cataract.

\section{Case Presentation}

Our patient's family history was unremarkable except for hearing loss in his father in his third decade. At age 40 years, our patient was diagnosed with left hearing loss. At age 41 years, he developed slowly progressive gait abnormalities. At age 45 years, he reported vision impairment with prominent hemeralopia, memory loss, and painful legs at night. Neurologic examination at age 45 years revealed moderate cerebellar ataxia-score of $12 / 40$ on the Scale for the Assessment and Rating of Ataxia-, areflexia, and a positive Romberg sign. Brain MRI showed bilateral supratentorial white matter abnormalities and cortical atrophy (eFigures 1, links.lww. com/NXG/A477). Nerve conduction studies revealed a severe bilateral axonal sensitive neuropathy of the 4 limbs. Audiometry showed bilateral perceptive hypoacusis.

Our patient had normal 20/20 visual acuity, but slit lamp examination demonstrated atypical bilateral lens inclusions with opacities. Fundus examination appeared grossly normal, but autofluorescence of the fundus revealed bilateral hyper-autofluorescence of the posterior pole and a patchy area of peripheral hyper fluorescence in the left eye. High-definition optical coherence tomography (OCT) disclosed bilateral hyper reflectivity of the retro-foveal region, located just below the ellipsoid line, with heterogeneity of the photoreceptor line. The electroretinogram revealed alteration of retinal electrogenesis in scotopic conditions consistent with the alterations observed on OCT (Figure, B).

\author{
Correspondence \\ Dr. Mochel \\ fanny.mochel@upmc.fr
}




\section{A}

Encephalopathy, Leigh syndrome (children)

$九$ Cardiomyopathy (children)

- Peripheral neuropathy $+/$ - ataxia (children)

- Cerebellar ataxia, neuropathy, sensory deficits (adult)

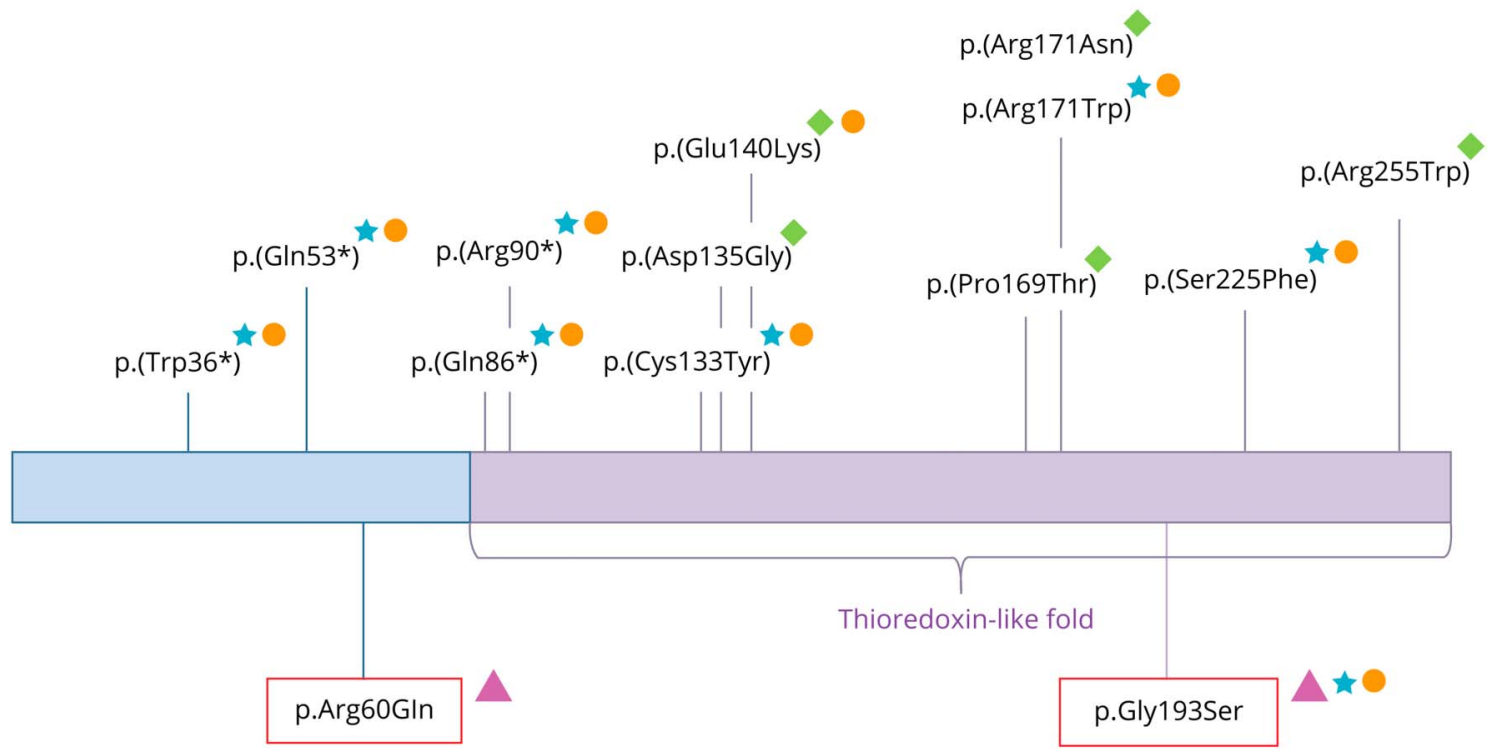

B
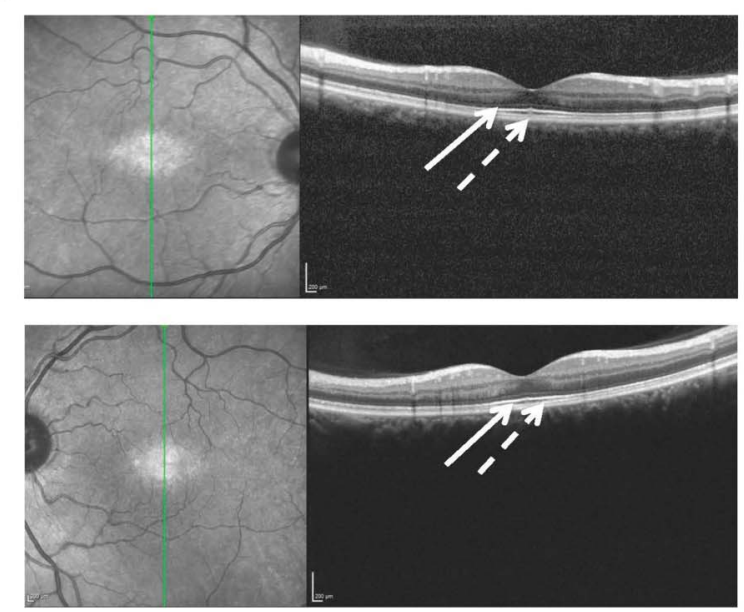

C

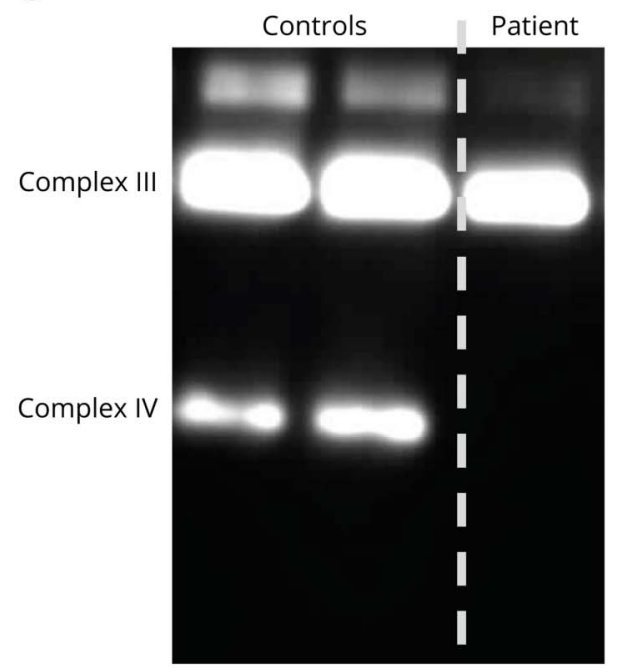

(A) Pathogenic SCO2 variants and related phenotypes. Underlined: previously reported variants; red box: variants of the presented case. (B) High-definition optical coherence tomography of the right (top) and left (bottom) eye, demonstrating bilateral hyper reflectivity of the retro-foveal area (plain arrow), located just below the ellipsoid line, with heterogeneity of the photoreceptor line (dashed arrow). (C) Blue native polyacrylamide gel electrophoresis (BN-PAGE) analysis of mitochondrial enriched fibroblasts of the SCO2-deficient patient and two controls using antibodies against respiratory chain complex subunits (complex III: UQCRC2; complex IV: MTCO1 and MTCO2).

CK enzymes were mildly but constantly elevated (range 320-376 U/L, N = 25-195 U/L). Metabolic investigations were normal, as well as molecular analyses of ATXN 1, 2, 3, 6, 7, and 17, FXN, and NOP56. Muscle biopsy showed a few fibers with lipid overload (i.e., lipid droplets) and a few COX negative or pale fibers. Spectrophotometric determination of mitochondrial respiratory chain enzyme activities as a ratio to citrate synthase activity showed isolated decreased activities of CIV in muscle and fibroblasts (Table).

We then analyzed our patient's leukocyte genomic DNA, after informed consent was obtained, using a next-generation sequencing panel (Roche NibelGen, Madison, WI), comprising the entire coding region and exon-intron junctions of 244 genes associated with mitochondrial diseases, and identified 2 
Table Spectrophotometric Assays of Respiratory Chain Activities in Muscle and Fibroblasts

\begin{tabular}{|c|c|c|c|c|}
\hline & Muscle & $\begin{array}{l}\text { Muscle } \\
\text { range }\end{array}$ & Fibroblasts & $\begin{array}{l}\text { Fibroblast } \\
\text { range }\end{array}$ \\
\hline \multicolumn{5}{|l|}{ Activities $^{a}$} \\
\hline $\mathrm{Cl}$ total & $71 \uparrow$ & $27-53$ & I & / \\
\hline $\mathrm{Cl}$ rotenone sensitive & $67 \uparrow$ & $22-48$ & / & / \\
\hline CII & $61 \uparrow$ & $25-45$ & $27 \uparrow$ & $11-19$ \\
\hline $\mathrm{CII}+\mathrm{CIII}$ & $57 \uparrow$ & $26-42$ & 25 & $14-29$ \\
\hline CIII total & $291 \uparrow$ & $184-242$ & & \\
\hline $\begin{array}{l}\text { CIII antimycin A } \\
\text { sensitive }\end{array}$ & $213 \uparrow$ & $92-166$ & $98 \uparrow$ & $33-67$ \\
\hline CIV & 181 & 109-193 & $19 \downarrow$ & $41-81$ \\
\hline CS & $320 \uparrow$ & $150-250$ & 54 & $31-65$ \\
\hline \multicolumn{5}{|l|}{ Ratios } \\
\hline $\mathrm{Cl} / \mathrm{CS}$ & 0.21 & $0.13-0.25$ & I & / \\
\hline $\mathrm{CII} / \mathrm{CS}$ & 0.19 & $0.13-0.25$ & $0.50 \uparrow$ & $0.24-0.38$ \\
\hline $\mathrm{CIII/CS}$ & 0.67 & $0.55-0.89$ & $1.81 \uparrow$ & $0.75-1.48$ \\
\hline CIV/CS & $0.57 \downarrow$ & $0.65-1.03$ & $0.35 \downarrow$ & $0.93-1.56$ \\
\hline
\end{tabular}

Abbreviation: CIV = complex IV

Values in bold represent either increased or decreased activities compared with normal ranges.

${ }^{\text {a }} \mathrm{mmol} / \mathrm{min} / \mathrm{mg}$ protein.

heterozygous missense variants in SCO2 (NM_005138.3: c. [179G $>\mathrm{A}]$; [577G $>\mathrm{A}]$ ) (Figure, A and eFigure 2, links.lww. com/NXG/A478): (1) a variant of unknown significanceACMG grading (PM2, PM3, PP2, and BP4)-, c.179G $>$ A p.(Arg60Gln), which modifies a conserved amino acid of the $\mathrm{N}$-terminal domain and predicted as possibly pathogenic by Polyphen; and (2) the c.577G>A p.(Gly193Ser) variant, reported as pathogenic and associated with infantile cardioencephalopathy. ${ }^{6}$ Each parent was heterozygous for a SCO2 variant. Blue native polyacrylamide gel electrophoresis on the patient's fibroblasts showed an almost complete absence of the CIV band, confirming isolated CIV deficiency (Figure, C). Given the discrepancy between our patient's phenotype and all pediatric patients reported so far with SCO2 deficiency, the patient and his parents underwent whole-genome sequencing. These independent analyses retrieved both $\mathrm{SCO} 2$ variants, but no other known pathogenic variants associated with cerebellar ataxia, peripheral neuropathy, hearing loss, or retinopathy.

\section{Discussion}

We present an adult-onset form of CIV deficiency related to biallelic $\mathrm{SCO} 2$ variants manifesting with a slowly progressive cerebellar ataxia after age 40 years, an axonal sensitive polyneuropathy, and bilateral sensory deficits with deafness, pigmentary retinopathy, and cataract.

Most of the damages caused by CIV deficiency are early and fatal, as reported so far with $\mathrm{SCO} 2$ pathogenic variants with pediatric and rapidly progressive disorders ${ }^{2-4}$ except for 2 children with a slower neurologic course. ${ }^{5}$ A possible explanation for the moderate phenotype of our patient relates to his genotype as he carries 2 missense variants, only 1 of which is located in the thioredoxin domain. Instead, pediatric cases carry either 2 missense variants in the thioredoxin domain or the association of one missense variant in the thioredoxin domain with a truncating variant (Figure, A). Unlike pediatric cases, our patient displayed both hearing and vision impairments with pigmentary retinopathy. Of interest, heterozygous $\mathrm{SCO} 2$ variants were also identified in dominant forms of severe myopia. ${ }^{7}$

\section{Acknowledgment}

The authors thank Sandrine Filaut et Laura Legrand for their help with NGS.

\section{Study Funding}

No targeted funding reported.

\section{Disclosure}

The authors report no disclosures relevant to the manuscript. Go to Neurology.org/NG for full disclosures.

\section{Publication History}

Received by Neurology: Genetics July 16, 2021. Accepted in final form August 12, 2021.

\section{References}

1. Banci L, Bertini I, Ciofi-Baffoni S, et al. A structural characterization of human SCO2. Structure. 2007;15(9):1132-1140.

2. Sacconi S, Salviati L, Sue CM, et al. Mutation screening in patients with isolated cytochrome c oxidase deficiency. Pediatr Res. 2003;53(2):224-230.

3. Szymanska-Debinska T, Karkucinska-Wieckowska A, Piekutowska-Abramczuk D, et al. Leigh disease due to SCO2 mutations revealed at extended autopsy. J Clin Pathol. 2015;68(5):397-399.

4. Rebelo AP, Saade D, Pereira CV, et al. SCO2 mutations cause early-onset axonal Charcot-Marie-Tooth disease associated with cellular copper deficiency. Brain. 2018; 141(3):662-672.

5. Barcia G, Assouline Z, Pennisi A, et al. Cytochrome c oxidase deficiency caused by biallelic $\mathrm{SCO} 2$ mutations in two sibs with cerebellar ataxia and progressive peripheral axonal neuropathy. Mol Genet Metab Rep. 2019; 21:100528.

6. Mobley BC, Enns GM, Wong LJ, Vogel H. A novel homozygous SCO2 mutation, p.G193S, causing fatal infantile cardioencephalomyopathy. Clin Neuropathol. 2009;28(2):143-149.

7. Tran-Viet KN, Powell C, Barathi VA, et al. Mutations in SCO2 are associated with autosomal-dominant high-grade myopia. Am J Hum Genet. 2013;92(5):820-826. 


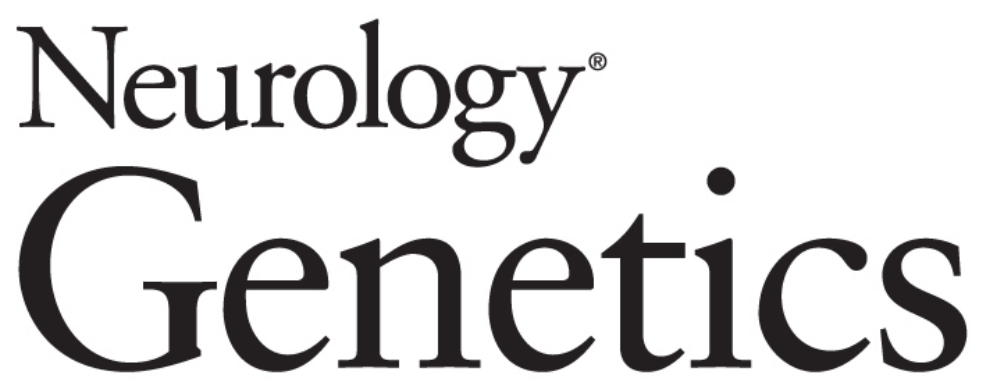

Adult Cerebellar Ataxia, Axonal Neuropathy, and Sensory Impairments Caused by Biallelic SCO2 Variants

Benoit Rucheton, Claire Ewenczyk, Pauline Gaignard, et al. Neurol Genet 2021;7;

DOI 10.1212/NXG.0000000000000630

This information is current as of November 4, 2021

Neurol Genet is an official journal of the American Academy of Neurology. Published since April 2015, it is an open-access, online-only, continuous publication journal. Copyright Copyright $(2021$ The Author(s). Published by Wolters Kluwer Health, Inc. on behalf of the American Academy of Neurology.. All rights reserved. Online ISSN: 2376-7839.

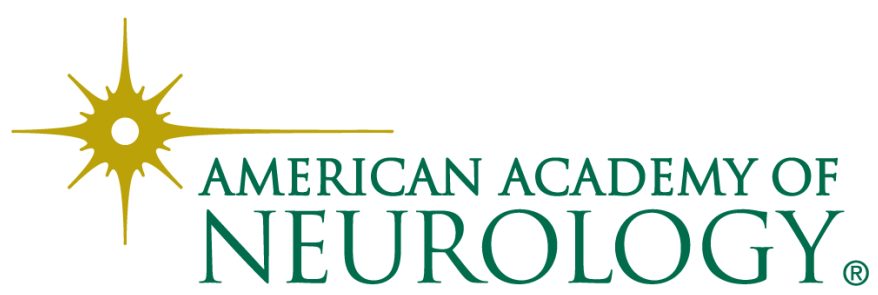




\section{Updated Information \& Services}

References

Subspecialty Collections

Permissions \& Licensing

\section{Reprints}

including high resolution figures, can be found at:

http://ng.neurology.org/content/7/6/e630.full.html

This article cites 7 articles, 1 of which you can access for free at: http://ng.neurology.org/content/7/6/e630.full.html\#\#ref-list-1

This article, along with others on similar topics, appears in the following collection(s):

\section{All Genetics}

http://ng.neurology.org//cgi/collection/all_genetics

\section{Mitochondrial disorders}

http://ng.neurology.org//cgi/collection/mitochondrial_disorders

Peripheral neuropathy

http://ng.neurology.org//cgi/collection/peripheral_neuropathy

\section{Retina}

http://ng.neurology.org//cgi/collection/retina

Spinocerebellar ataxia

http://ng.neurology.org//cgi/collection/spinocerebellar_ataxia

Information about reproducing this article in parts (figures,tables) or in its entirety can be found online at:

http://ng.neurology.org/misc/about.xhtml\#permissions

Information about ordering reprints can be found online:

http://ng.neurology.org/misc/addir.xhtml\#reprintsus

Neurol Genet is an official journal of the American Academy of Neurology. Published since April 2015, it is an open-access, online-only, continuous publication journal. Copyright Copyright $\odot 2021$ The Author(s). Published by Wolters Kluwer Health, Inc. on behalf of the American Academy of Neurology.. All rights reserved. Online ISSN: 2376-7839.

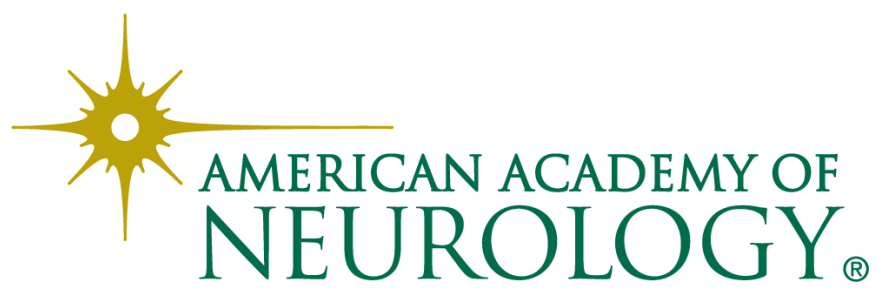

